\title{
PROFITABILITY OF COARSE CEREALS PRODUCTION IN INDIA
}

\author{
Birhanu Ayalew ${ }^{* 1}$, I. Sekar ${ }^{2}$ \\ ${ }^{1}$ Ethiopian Institute of Agricultural Research, Ethiopi \\ ${ }^{2}$ Principal Scientist, Indian Agricultural Research Institute, New Delhi \\ "E-mail address: birhanua08@gmail.com
}

Keywords: Coarse Cereals; Cost Concept; Farm Business Income; Profitability

\begin{abstract}
This study was aimed at investigating profitability of selected coarse cereals production in major producing states of India through analyzing cost, return and profitability of coarse cereals cultivation. Cost concepts and farm business income measures used for analysis the data ranging from 1980-81 to 2011-12. Net return of coarse cereals cultivation was observed to be highest for maize and it was highest in Bihar (Rs. 15,429/ha) and lowest Uttar Pradesh (Rs. -4,006/ha). Net return from cultivation of sorghum was found to be highest in Andhra Pradesh (Rs. 952/ha) and lowest for Madhya Pradesh (Rs. -1,456/ha). For pearl millet net return was highest in Andhra Pradesh (Rs. 4,995/ha) and lowest for Karnataka (Rs. -1,252/ha) whereas cultivation of finger millet was observed to be at a loss.
\end{abstract}

\section{INTRODUCTION}

Coarse cereals are group of crops that consists of all cereals except rice and wheat mainly maize, sorghum, pearl millet, barley, finger millet and small millets. These crops are grown in different parts of the world for different purposes mainly in the developing countries of Africa and Asia, which contribute more of area but less of production due to low productivity. These countries are also home for the majority of poor, malnourished and food insecure. Grown in the marginal land with minimum input, coarse cereals gained popularity and higher acceptability by the hundreds of millions of subsistence farmers. They also have the potential to improve the food and nutritional security of the world poor since they are more nutritious than the superior cereals. They are rich in nutrients, minerals and vitamins and less in carbohydrate and gluten free nature of these crops also brought about shift in the consumption pattern in the calorie conscious life style.

In addition to coarse cereals' food value and benefits, they are currently being used for different industrial uses including biofuel for the ever increasing demand and alternative sources of safer energy. Moreover, the increasing demand of meat and dairy products in the world has also resulted in more demand of coarse cereals for feed. The multiple uses of these crops have also brought about increase in the demand.

India is on the top list of coarse cereals producers in the world in terms of area and production. Coarse cereals had been traditionally the main components of the food basket of the poor in India. However, it is now considered as one of the neglected crop sectors. These are predominantly grown in the resource fragile agro climatic regions of the country mainly in Karnataka, Maharashtra, Tamil Nadu, Madhya Pradesh, Rajasthan and Gujarat. In addition to agricultural allied sectors' demand, it offers a good potential in food processing industry and as a promising exportable commodity. The acreage under coarse cereals has declined. Despite area decline, the production of coarse cereals has increased now as compared to eighties. Maize is one of the major coarse cereals, and its production has increased in particular. Such production increase has been demanded driven from livestock sector. But the performance of other coarse cereals continues to be dismal. The poor production performances and relative profitability of other coarse cereals like pearl millet, sorghum, finger millet, and millets are little studied of late. With this back drop, this study is aimed at investigating profitability of selected coarse cereals in major producing states of India. 


\section{DATA AND METHODOLOGY}

The study is based on secondary data during time period (1980-81 to 2011-12), which is collected from various published sources. Data on costs and farm harvest prices of major coarse cereals in India were collected from Directorate of Economics and Statistics, Ministry of Agriculture, Government of India. For the analysis of cost and returns of the selected coarse cereals in major coarse cereals producing states, costs concept and farm business income measures were used.

\section{Cost concept}

1. Cost $\mathbf{A}_{1}$ : It includes all actual expenses in cash and kind incurred in production by the farmer.

i) Value of hired human labour

ii) Value of bullock labour (both hired and owned)

iii) Value of machine power (both hired and owned)

iv) Value of seeds (both owned and purchased)

v) Value of insecticides and pesticides, weedicides

vi) Value of manures (both owned and purchased)

vii) Value of fertilizers

viii) Depreciation of implements and farm buildings

ix) Irrigation charges

$\mathrm{x})$ Land revenue, cess and other taxes

xi) Miscellaneous expenses (electricity charges etc)

xii) Interest on working capital

2. Cost $\mathbf{A}_{2}:$ Cost $A_{1}+$ rent paid for leased in- land

3. Cost $\mathbf{B}_{1}$ : Cost $A_{2}+$ interest on value of owned capital assets (excluding land)

4. Cost $B_{2}$ : Cost $B_{1}+$ rental value of owned land

5. Cost $\mathbf{C}_{1}$ : Cost $\mathrm{B}_{1}+$ imputed value of family labour

6. Cost $\mathbf{C}_{2}$ : Cost $\mathrm{B}_{2}+$ imputed value of family labour

7. Cost $C_{2}$ revised: Cost $C_{2} \times 1.10\left(10 \%\right.$ of cost $C_{2}$ is added to cost $\left.C_{2}\right)$ : this is a recently added concept to provide allowance for managerial functions undertaken by the farmer. It is the total cost or comprehensive cost of cultivation.

Cost of production $=\left(\right.$ Cost $\left.\mathrm{C}_{2}\right) /$ Yield

Interest on present value of fixed capital assets charged at the rate of $10 \%$ per annum. Interest on working capital is charged at the rate of capital $12.5 \%$ per annum for half the period of crop.

Farm business income measures:

1. Gross returns: Value of main product plus by-product.

2. Net income $=$ Gross return-Cost $\mathrm{C}_{2}$ revised

3. Net return to Cost $\mathbf{A}_{2}=$ Gross return - Cost $A_{2}$

4. Net return to $\mathbf{C}_{\mathbf{2}}=$ Gross return - Cost $\mathrm{C}_{2}$

5. Profitability $=$ Net return $/$ Cost

6. Benefit Cost Ratio $(\mathbf{B C R})=$ Gross Return $/$ Total Cost

\section{RESULTS AND DISCUSSION}

\subsection{Profitability of Maize Production in India}

Maize is one of the major coarse cereal crop in the country. Cost and return of maize varies in states of India were analysed and it was found that the average cost of cultivation of maize was highest in Andhra Pradesh,Rs. 26,563/ha, of which variable cost and fixed cost were 65\% and 35\% respectively. It was observed to be lowest in Madhya Pradesh,Rs. 9,340/ha, of which variable cost formed about $73 \%$. The expenditure on human labour was a major component in variable cost in all the states. Similarly, rental value of the land formed major component among fixed costs in TE 2010-11. Human labour requirement was highest in Andhra Pradesh,647.11 man hours per hectare followed by Rajasthan, 619.42 man hours per hectare and lowest in Madhya Pradesh, 416.32 man hours per hectare. Chemical fertilizer used was highest in Andhra Pradesh, $221 \mathrm{~kg} / \mathrm{ha}$ and lowest in 
Madhya Pradesh, 43kg/ha. Irrigation charge was found to be highest in Bihar (Rs. 2,090/ha) followed by Andhra Pradesh(Rs. 1,067/ha).

Gross return of maize cultivation was observed to be highest in Bihar, Rs. 29,959/ha followed by Andhra Pradesh (Rs. 27,840/ha) and lowest in Madhya Pradesh, Rs. 7261/ha. Net return from cultivation of maize was highest in Bihar (Rs. 15,429/ha) but negative in Uttar Pradesh(Rs.4,006/ha) and Madhya Pradesh (Rs. -2,079/ha). Benefit cost ratio (BCR) was also highest in Bihar (2.06) but lowest in Uttar Pradesh (0.73) and Madhya Pradesh (0.78). Even though yield was highest in Andhra Pradesh (46 qt/ha), BCR was observed to be low due to high cost of cultivation from input intensive production and high cost of human labour. In Madhya Pradesh, BCR was less than one due to high cost of production and low yield (11qt/ha). In Bihar, high yield coupled with low cost of human labour resulted in highest BCR (Table - 1).

In Bihar, over the years 1996-97 to 2010-11 the net return over $A_{2}$ from maize has increased by about $11 \%$ per annum due to about $7 \%$ per year increase in gross return. The increase in gross return was mainly due to annual increase of productivity by $5.57 \%$ as the increase in real price of maize was only $1.04 \%$. More over the increase in yield has resulted in increase in the cost of production by only $1.34 \%$ annually. The scenario in Uttar Pradesh has been different from Bihar. Net return in Uttar Pradesh has shown a marginal increase over the years $(0.3 \%)$ due to higher increase in cost of cultivation (4.29\%) than gross return $(3.05 \%)$. The increase in yield was only about $2 \%$ per year so that cost of production has increased by about $2 \%$. In the same manner BCR of maize in Bihar has increased (4.7\% per year) while it has decreased in Uttar Pradesh (-1.18\% per year) (Table-2).

\subsection{Profitability of Sorghum Production in India}

State wise cost and return estimate of sorghum was done based on data during the time period TE 2010-11. The average cost of cultivation of sorghum was found to be highest in Andhra Pradesh (Rs. 15,569/ha) and lowest in Rajasthan (Rs. 6,209/ha). Among the variable inputs, human labour was observed to be the highest in Maharashtra (519 man hrs) and lowest in Rajasthan (298 man hrs). Gross return was highest in Andhra Pradesh (Rs. 16,521/ha) and lowest in Rajasthan (Rs. 6,133/ha). Net return and BCR of Andhra Pradesh were Rs. 952/ha and 1.06 respectively, which were observed to be the highest. In Madhya Pradesh, sorghum production was at a loss of Rs. $1,456 /$ ha and BCR of 0.83 . The lowest BCR in Madhya Pradesh could be due to low productivity (11 qt/ha) along with lower remunerative price (Table - 3).

Gross return and cost of cultivation from sorghum over the period 1999-2000 to 2010-11 has increased for both Maharashtra and Andhra Pradesh but were higher for the latter. The net return from $\mathrm{A}_{2}$ has increased for Andhra Pradesh (14\% per year) than for Maharashtra (3.21\% per year) due to increase in real price of sorghum in Andhra Pradesh (5.89\%) but lesser increase in Maharashtra (1.66\%). Therefore, BCR of sorghum cultivation has increased at a rate of $3.43 \%$ in Andhra Pradesh but only $0.33 \%$ per year for Maharashtra (Table - 4).

\subsection{Profitability of Pearl millet Production in India}

Cost and return analysis was undertaken for pearl millet, another important cereal crop. Production of pearl millet observed to be input intensive in Gujarat as compared to other states with high level of chemical fertilizer and human labour. Cost of cultivation of pearl millet was observed to be highest in Maharashtra (Rs. 15,181/ha) and lowest in Karnataka (Rs. 5,749/ha). Gross return from cultivation of pearl millet was highest in Gujarat (Rs. 18,115/ha) and lowest in Karnataka (Rs. 4,497/ha).Net return over $\mathrm{C}_{2}$ and BCR were also highest in Gujarat and lowest in Karnataka. The change in net return might be due to regional variation in productivity and price of output among the states (Table - 5). 
Table 1: Cost and return of maize in selected states of India in TE2010-11

\begin{tabular}{|c|c|c|c|c|c|c|c|c|c|c|c|c|}
\hline \multirow{2}{*}{ Particulars } & \multicolumn{2}{|c|}{ Andhra Pradesh } & \multicolumn{2}{|c|}{ Bihar } & \multicolumn{2}{|c|}{ Karnataka } & \multicolumn{2}{|c|}{ Madhya Pradesh } & \multicolumn{2}{|c|}{ Rajasthan } & \multicolumn{2}{|c|}{ Uttar Pradesh } \\
\hline & $\begin{array}{l}\text { Value } \\
\text { (Rs.) }\end{array}$ & Percent & $\begin{array}{l}\text { Value } \\
\text { (Rs.) }\end{array}$ & Percent & $\begin{array}{l}\text { Value } \\
\text { (Rs.) }\end{array}$ & Percent & $\begin{array}{l}\text { Value } \\
\text { (Rs.) }\end{array}$ & Percent & $\begin{array}{l}\text { Value } \\
\text { (Rs.) }\end{array}$ & Percent & $\begin{array}{l}\text { Value } \\
\text { (Rs.) }\end{array}$ & Percent \\
\hline Operational Cost & 17270 & 65.01 & 10035 & 71.33 & 9850 & 67.51 & 6795 & 72.75 & 10826 & 71.22 & 10076 & 66.97 \\
\hline Fixed Costs & 9293 & 34.99 & 4034 & 28.67 & 4740 & 32.49 & 2545 & 27.25 & 4374 & 28.78 & 4969 & 33.03 \\
\hline Total Cost & 26563 & 26563 & 14070 & & 14590 & & 9340 & & 15199 & & 15045 & \\
\hline Gross return (Rs./ha) & 27840 & & 29959 & & 18892 & & 7261 & & 15641 & & 11040 & \\
\hline Cost $A_{2}(\mathrm{Rs} / \mathrm{ha})$ & 15021 & & 8696 & & 8121 & & 4434 & & 7333 & & 6530 & \\
\hline Net return over $\mathrm{A}_{2}(\mathrm{Rs} / \mathrm{ha})$ & 12819 & & 21263 & & 10771 & & 2827 & & 8308 & & 4510 & \\
\hline Profitability (Net return as $\%$ of $\mathrm{A}_{2}$ ) & & 85.34 & & 244.53 & & 132.64 & & 63.74 & & 113.3 & & 69.07 \\
\hline Cost $\mathrm{C}_{2}$ (Rs/ha) & 26657 & & 14530 & & 14869 & & 9340 & & 15223 & & 15045 & \\
\hline Net return over $C_{2}(\mathrm{Rs} / \mathrm{ha})$ & 1183 & & 15429 & & 4023 & & -2079 & & 418 & & -4006 & \\
\hline Profitability (Net return as $\%$ of $\mathrm{C}_{2}$ ) & & 4.44 & & 106.19 & & 27.06 & & -22.26 & & 2.74 & & -26.62 \\
\hline Productivity (qt/ha) & 46 & & 38 & & 31 & & 11 & & 20 & & 17 & \\
\hline Gross return (Rs/qt) & 605 & & 788 & & 603 & & 654 & & 802 & & 660 & \\
\hline Cost of production $\left(\mathrm{C}_{2}\right)(\mathrm{Rs} / \mathrm{qt})$ & 552 & & 329 & & 429 & & 673 & & 576 & & 807 & \\
\hline $\mathrm{BCR}$ & 1.04 & & 2.06 & & 1.27 & & 0.78 & & 1.03 & & 0.73 & \\
\hline
\end{tabular}

Author's calculation based on data from DES, GOI

Table 2: Cost and return of maize in selected states of India

\begin{tabular}{|c|c|c|c|c|c|c|c|c|c|c|c|c|c|c|}
\hline \multirow{2}{*}{$\begin{array}{l}\text { Year } \\
(\mathrm{TE})\end{array}$} & \multicolumn{7}{|c|}{ Bihar } & \multicolumn{7}{|c|}{ Uttar Pradesh } \\
\hline & $\begin{array}{c}\text { Gross return } \\
\text { (Rs./ha) }\end{array}$ & $\begin{array}{l}\text { Cost } A_{2} \\
(\mathrm{Rs} / \mathrm{ha}) \\
\end{array}$ & $\begin{array}{c}\text { Net return } \\
\text { over } A_{2} \\
\text { (Rs./ha) } \\
\end{array}$ & $\begin{array}{c}\text { Productivity } \\
\text { (qt/ha) }\end{array}$ & $\begin{array}{c}\text { FHP } \\
\text { (Rs/qt) }\end{array}$ & $\begin{array}{c}\text { Cost of } \\
\text { production } \\
(\mathrm{Rs} / \mathrm{q} \text { t) }\end{array}$ & $\mathrm{BCR}$ & $\begin{array}{c}\text { Gross } \\
\text { return } \\
\text { (Rs./ha) } \\
\end{array}$ & $\begin{array}{l}\text { Cost } A_{2} \\
(\mathrm{Rs} / \mathrm{ha}) \\
\end{array}$ & $\begin{array}{c}\text { Net return } \\
\text { over } A_{2} \\
\text { (Rs. } / \text { ha) } \\
\end{array}$ & $\begin{array}{c}\text { Productivity } \\
\text { (qt/ha) }\end{array}$ & $\begin{array}{c}\text { FHP } \\
\text { (Rs/qt) }\end{array}$ & $\begin{array}{c}\text { Cost of } \\
\text { production } \\
(\mathrm{Rs} / \mathrm{q} t)\end{array}$ & $\mathrm{BCR}$ \\
\hline 1998-99 & 13628 & 6653 & 6975 & 20.59 & 575 & 666 & 2.05 & 7889 & 3587 & 4302 & 12.69 & 553 & 285 & 2.20 \\
\hline \multicolumn{15}{|l|}{ 2001-02 } \\
\hline & 11910 & 7660 & 4250 & 22.93 & 456 & 519 & 1.55 & 8437 & 4848 & 3589 & 16.14 & 481 & 300 & 1.74 \\
\hline \multicolumn{14}{|l|}{ 2004-05 } & 1.92 \\
\hline \multicolumn{15}{|l|}{ 2007-08 } \\
\hline & 19181 & 8264 & 10917 & 36.94 & 454 & 520 & 2.32 & 10035 & 4961 & 5073 & 17.61 & 499 & 285 & 2.02 \\
\hline \multicolumn{15}{|l|}{ 2010-11 } \\
\hline & 29959 & 8696 & 21263 & 38.00 & 654 & 792 & 3.45 & 11040 & 6530 & 4510 & 16.72 & 575 & 402 & 1.69 \\
\hline \multicolumn{15}{|c|}{ CAGR (\%) } \\
\hline & 6.99 & 2.19 & 10.89 & 5.57 & 1.04 & 1.34 & 4.7 & 3.05 & 4.29 & 0.3 & 2.32 & 0.49 & 1.92 & -1.18 \\
\hline \multicolumn{15}{|l|}{ CV (\%) } \\
\hline & 36.95 & 10.8 & 59.17 & 25.95 & 18.5 & 21.74 & 29.8 & 19.4 & 27.14 & 35.27 & 19.31 & 13.12 & 24.28 & 20.02 \\
\hline
\end{tabular}


Table 3: Cost and return of sorghum in selected states of India in TE2010-11

\begin{tabular}{|c|c|c|c|c|c|c|c|c|c|c|c|c|}
\hline \multirow{2}{*}{ Particulars } & \multicolumn{2}{|c|}{ Andhra Pradesh } & \multicolumn{2}{|c|}{ Karnataka } & \multicolumn{2}{|c|}{ Madhya Pradesh } & \multicolumn{2}{|c|}{ Maharashtra } & \multicolumn{2}{|c|}{ Rajasthan } & \multicolumn{2}{|c|}{ Tamil Nadu } \\
\hline & $\begin{array}{l}\text { Value } \\
\text { (Rs.) }\end{array}$ & Percent & $\begin{array}{l}\text { Value } \\
\text { (Rs.) }\end{array}$ & Percent & $\begin{array}{l}\text { Value } \\
\text { (Rs.) }\end{array}$ & Percent & $\begin{array}{l}\text { Value } \\
\text { (Rs.) }\end{array}$ & Percent & $\begin{array}{l}\text { Value } \\
\text { (Rs.) }\end{array}$ & Percent & $\begin{array}{l}\text { Value } \\
\text { (Rs.) }\end{array}$ & Percent \\
\hline Operational Cost & 9675 & 62.14 & 5156 & 70.62 & 5889 & 70.03 & 8958 & 67.79 & 4480 & 72.15 & 5819 & 77.26 \\
\hline Fixed Costs & 5894 & 37.86 & 2145 & 29.38 & 2520 & 29.97 & 4256 & 32.21 & 1729 & 27.85 & 1713 & 22.74 \\
\hline Total Cost & 15569 & & 7301 & & 8410 & & 13214 & & 6209 & & 7532 & \\
\hline Gross return (Rs./ha) & 16521 & & 6993 & & 6954 & & 13684 & & 6133 & & 7737 & \\
\hline Cost $A_{2}$ (Rs/ha) & 7910 & & 4185 & & 4325 & & 7660 & & 2340 & & 4532 & \\
\hline Net return over $\mathrm{A}_{2}(\mathrm{Rs} / \mathrm{ha})$ & 8612 & & 2808 & & 2629 & & 6024 & & 3792 & & 3205 & \\
\hline \multicolumn{2}{|c|}{ Profitability (Net return as $\%$ of $\mathrm{A}_{2}$} & 108.88 & & 67.11 & & 60.78 & & 78.64 & & 162.06 & & 70.71 \\
\hline Cost $C_{2}$ (Rs/ha) & 15569 & & 7301 & & 8410 & & 13214 & & 6209 & & 7532 & \\
\hline Net return over $\mathrm{C}_{2}(\mathrm{Rs} / \mathrm{ha})$ & 952 & & -308 & & -1456 & & 470 & & -76 & & 205 & \\
\hline \multicolumn{2}{|c|}{ Profitability (Net return as $\%$ of $\mathrm{C}_{2}$ ) } & 6.12 & & -4.22 & & -17.31 & & 3.56 & & -1.23 & & 2.72 \\
\hline Productivity (qt/ha) & 16 & & 8 & & 11 & & 13 & & 5 & & 8 & \\
\hline Gross return (Rs/qt) & 1028 & & 894 & & 621 & & 1044 & & 1355 & & 997 & \\
\hline Cost of production $\left(\mathrm{C}_{2}\right)$ (Rs/qt) & 892 & & 782 & & 596 & & 660 & & 571 & & 606 & \\
\hline BCR & 1.06 & & 0.96 & & 0.83 & & 1.04 & & 0.99 & & 1.03 & \\
\hline
\end{tabular}

Author's calculation based on data from DES, GOI

Table 4: Cost and return of sorghum in selected states of India

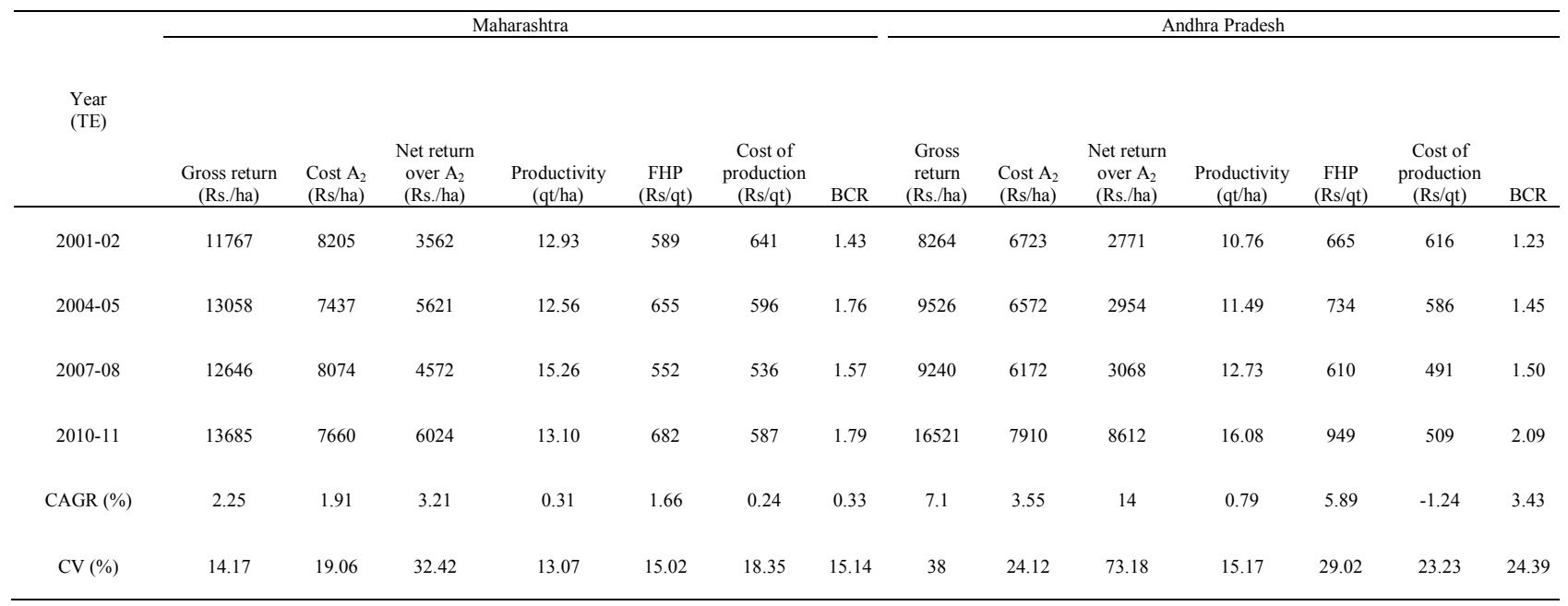

Author's calculation based on data from DES, GOI

Over the period 1999-2000 to 2010-11, gross return from cultivation of pearl millet has increased for Gujarat (3.43\%) and Rajasthan $(2.89 \%)$ coupled with increase in the growth rate of cost of cultivation at a rate of $1.51 \%$ for Gujarat and $3.44 \%$ for Rajasthan. A marginal increase in real price of produce and more than $2.5 \%$ increase in yield resulted in increase of net return and decline in cost of production in Gujarat. As a result, the BCR of pearl millet cultivation has declined marginally for Rajasthan at a rate of $-0.53 \%$ but for Gujarat increased at a rate of $1.89 \%$ per year (Table - 6).

\subsection{Profitability of Finger millet Production in India}

The profitability analysis of finger millet has shown that it is not a profitable crop overall. The operational cost of finger millet observed to be highest in Maharashtra (Rs. 16,626/ha) and was around $75 \%$ of total cost of cultivation. Among the variable costs, the share of human labor was observed to be more than $40 \%$ for all the states taken in to consideration showing labour intensive production of finger millet. BCR of finger millet cultivation was highest in Tamil Nadu (1.26) due 
to higher yield and price of produce but was low in Maharashtra (0.63) due to higher cost of production mainly human labour (Table - 7).

Over the period 1999-2000 to 2010-11, gross return from finger millet has shown an increase for both the states of Tamil Nadu (4.53\% per annum) and Karnataka (3.80\% per annum) but cost of cultivation has declined at a rate of $-3.5 \%$ per annum for Tamil Nadu while has increased at a rate of $2.09 \%$ for Karnataka. Yield of finger millet has increased at $4.41 \%$ per annum for Tamil Nadu but only $1.62 \%$ was seen in Karnataka. However, real price has increased for the latter and marginally declined for the former. As a result, net return from finger millet cultivation has shown impressive growth in Tamil Nadu (20.12\%) and 8.04\% per year for Karnataka. More over cost of production has declined (-7.58\%) and BCR increased by $8.32 \%$ in Tamil Nadu (Table - 8).

Table 5: Cost and return of pearl millet in selected states of India in TE2010-11

\begin{tabular}{|c|c|c|c|c|c|c|c|c|c|c|c|c|}
\hline \multirow{3}{*}{ Particulars } & \multicolumn{2}{|c|}{ Gujarat } & \multicolumn{2}{|c|}{ Haryana } & \multicolumn{2}{|c|}{ Karnataka } & \multicolumn{2}{|c|}{ Maharashtra } & \multicolumn{2}{|c|}{ Rajasthan } & \multicolumn{2}{|c|}{ Uttar Pradesh } \\
\hline & & & Value & & Value & & Value & & Value & & Value & \\
\hline & $\begin{array}{l}\text { Value } \\
\text { (Rs.) }\end{array}$ & percent & (Rs.) & percent & (Rs.) & Percent & (Rs.) & percent & (Rs.) & percent & (Rs.) & percent \\
\hline Operational Cost & 9376 & 71.46 & 7989 & 61.69 & 4387 & 76.32 & 10980 & 72.33 & 4817 & 68.97 & 7237 & 60.14 \\
\hline Fixed Costs & 3744 & 28.54 & 4961 & 38.31 & 1361 & 23.68 & 4201 & 27.67 & 2167 & 31.03 & 4796 & 39.86 \\
\hline Total Cost & 13120 & 100 & 12950 & 100 & 5748 & 100 & 15181 & 100 & 6983 & 100 & 12032 & 100 \\
\hline Gross return (Rs./ha) & 18115 & & 12399 & & 4497 & & 14045 & & 8068 & & 11096 & \\
\hline Cost $A_{2}$ (Rs/ha) & 7338 & & 4528 & & 3573 & & 8858 & & 2361 & & 4740 & \\
\hline Net return over $\mathrm{A}_{2}$ (Rs/ha) & 10777 & & 7871 & & 924 & & 5188 & & 5707 & & 6356 & \\
\hline Profitability (Net return as $\%$ of $A_{2}$ ) & & 146.86 & & 173.85 & & 25.85 & & 58.57 & & 241.7 & & 134.1 \\
\hline Cost $C_{2}(\mathrm{Rs} / \mathrm{ha})$ & 13120 & & 12950 & & 5748 & & 15181 & & 6983 & & 12032 & \\
\hline Net return over $\mathrm{C}_{2}(\mathrm{Rs} / \mathrm{ha})$ & 4995 & & -551 & & -1252 & & -1136 & & 1085 & & -936 & \\
\hline Profitability (Net return as $\%$ of $\mathrm{C}_{2}$ ) & & 38.07 & & -4.26 & & -21.77 & & -7.48 & & 15.53 & & -7.78 \\
\hline Productivity (qt/ha) & 21 & & 19 & & 8 & & 19 & & 9 & & 20 & \\
\hline Gross return (Rs/qt) & 860 & & 661 & & 542 & & 739 & & 867 & & 558 & \\
\hline Cost of production $\left(\mathrm{C}_{2}\right)(\mathrm{Rs} / \mathrm{q} \mathrm{t})$ & 451 & & 553 & & 642 & & 638 & & 432 & & 476 & \\
\hline BCR & 1.38 & & 0.96 & & 0.78 & & 0.93 & & 1.16 & & 0.92 & \\
\hline
\end{tabular}

Author's calculation based on data from DES, GOI

Table 6: Cost and return of pearl millet in selected states of India

\begin{tabular}{|c|c|c|c|c|c|c|c|c|c|c|c|c|c|c|}
\hline \multirow{2}{*}{$\begin{array}{l}\text { Year } \\
\text { (TE) }\end{array}$} & \multicolumn{7}{|c|}{ Gujarat } & \multicolumn{7}{|c|}{ Rajasthan } \\
\hline & $\begin{array}{c}\text { Gross return } \\
\text { (Rs./ha) }\end{array}$ & $\begin{array}{l}\text { Cost } A_{2} \\
(\mathrm{Rs} / \mathrm{ha}) \\
\end{array}$ & $\begin{array}{c}\text { Net return } \\
\text { over } \mathrm{A}_{2} \\
\text { (Rs./ha) } \\
\end{array}$ & $\begin{array}{c}\text { Productivity } \\
\text { (qt/ha) }\end{array}$ & $\begin{array}{c}\text { FHP } \\
(\mathrm{Rs} / \mathrm{qt})\end{array}$ & $\begin{array}{c}\text { Cost of } \\
\text { production } \\
(\mathrm{Rs} / \mathrm{q} t)\end{array}$ & $\mathrm{BCR}$ & $\begin{array}{c}\text { Gross } \\
\text { return } \\
\text { (Rs./ha) }\end{array}$ & $\begin{array}{l}\text { Cost } A_{2} \\
(\mathrm{Rs} / \mathrm{ha})\end{array}$ & $\begin{array}{c}\text { Net return } \\
\text { over } \mathrm{A}_{2} \\
\text { (Rs./ha) } \\
\end{array}$ & $\begin{array}{c}\text { Productivity } \\
\text { (qt/ha) }\end{array}$ & $\begin{array}{c}\text { FHP } \\
\text { (Rs/qt) }\end{array}$ & $\begin{array}{c}\text { Cost of } \\
\text { production } \\
(\mathrm{Rs} / \mathrm{q} \mathrm{t})\end{array}$ & $\mathrm{BCR}$ \\
\hline 2001-02 & 12583 & 6401 & 6181 & 15.35 & 589 & 419 & 1.97 & 5221 & 1829 & 3392 & 7.12 & 427 & 263 & 2.85 \\
\hline 2004-05 & 12151 & 7172 & 4979 & 15.84 & 560 & 453 & 1.69 & 8481 & 2305 & 6176 & 9.16 & 531 & 266 & 3.68 \\
\hline 2007-08 & 14440 & 7422 & 7017 & 18.25 & 593 & 407 & 1.95 & 6406 & 2228 & 4178 & 7.73 & 534 & 298 & 2.87 \\
\hline $2010-11$ & 18115 & 7338 & 10777 & 21.07 & 602 & 349 & 2.47 & 8068 & 2361 & 5707 & 9.31 & 495 & 261 & 3.42 \\
\hline CAGR (\%) & 3.43 & 1.51 & 5.21 & 2.87 & 0.16 & -1.33 & 1.89 & 2.89 & 3.44 & 2.68 & 2.53 & 0.72 & 0.89 & -0.53 \\
\hline CV (\%) & 18.4 & 10.3 & 31.79 & 16.5 & 5.99 & 10.62 & 15.11 & 22.22 & 16.7 & 27.6 & 24 & 16.64 & 20.31 & 17.15 \\
\hline
\end{tabular}

Author's calculation based on data from DES, GOI 
Table 7: Cost and return of finger millet in selected states of India in TE 2010-11

\begin{tabular}{|c|c|c|c|c|c|c|}
\hline \multirow[b]{2}{*}{ Particulars } & \multicolumn{2}{|c|}{ Karnataka } & \multicolumn{2}{|c|}{ Maharashtra } & \multicolumn{2}{|c|}{ Tamil Nadu } \\
\hline & $\begin{array}{l}\text { Value } \\
\text { (Rs.) }\end{array}$ & Percent & $\begin{array}{l}\text { Value } \\
\text { (Rs.) }\end{array}$ & Percent & $\begin{array}{l}\text { Value } \\
\text { (Rs.) }\end{array}$ & Percent \\
\hline Operational Cost & 11279 & 71.66 & 16626 & 75.58 & 10888 & 75.43 \\
\hline Fixed Costs & 4461 & 28.34 & 5371 & 24.42 & 3547 & 24.57 \\
\hline Total Cost & 15740 & & 21997 & & 14434 & \\
\hline Gross return (Rs./ha) & 12519 & & 13963 & & 18234 & \\
\hline Cost $A_{2}(\mathrm{Rs} / \mathrm{ha})$ & 8770 & & 13177 & & 7156 & \\
\hline Net return over $\mathrm{A}_{2}(\mathrm{Rs} / \mathrm{ha})$ & 3749 & & 787 & & 11078 & \\
\hline Profitability (Net return as $\%$ of $\mathrm{A}_{2}$ ) & & 42.74 & & 5.97 & & 154.8 \\
\hline $\operatorname{Cost} \mathrm{C}_{2}(\mathrm{Rs} / \mathrm{ha})$ & 15740 & & 21997 & & 14434 & \\
\hline Net return over $\mathrm{C}_{2}(\mathrm{Rs} / \mathrm{ha})$ & -6970 & & -8820 & & -7278 & \\
\hline Profitability (Net return as $\%$ of $\mathrm{C}_{2}$ ) & & -44.28 & & -40.1 & & -50.42 \\
\hline Productivity (qt/ha) & 16 & & 18 & & 25 & \\
\hline Gross return (Rs/qt) & 804 & & 786 & & 737 & \\
\hline Cost of production $\left(\mathrm{C}_{2}\right)(\mathrm{Rs} / \mathrm{qt})$ & 787 & & 1157 & & 534 & \\
\hline BCR & 0.8 & & 0.63 & & 1.26 & \\
\hline
\end{tabular}

Author's calculation based on data from DES, GOI

Table 8: Cost and return of finger millet in selected states of India

\begin{tabular}{|c|c|c|c|c|c|c|c|c|c|c|c|c|c|c|}
\hline \multirow{3}{*}{$\begin{array}{l}\text { Year } \\
\text { (TE) }\end{array}$} & \multicolumn{7}{|c|}{ Tamil Nadu } & \multicolumn{7}{|c|}{ Karnataka } \\
\hline & & & & & & & & & & & & & & \\
\hline & $\begin{array}{c}\text { Gross return } \\
\text { (Rs./ha) }\end{array}$ & $\begin{array}{l}\text { Cost } A_{2} \\
(\mathrm{Rs} / \mathrm{ha})\end{array}$ & $\begin{array}{c}\text { Net return } \\
\text { over } \mathrm{A}_{2} \\
\text { (Rs. } / \text { ha) }\end{array}$ & $\begin{array}{c}\text { Productivity } \\
\text { (qt/ha) }\end{array}$ & $\begin{array}{c}\text { FHP } \\
\text { (Rs/qt) }\end{array}$ & $\begin{array}{c}\text { Cost of } \\
\text { production } \\
\text { (Rs/qt) }\end{array}$ & BCR & $\begin{array}{c}\text { Gross } \\
\text { return } \\
\text { (Rs./ha) }\end{array}$ & $\begin{array}{l}\text { Cost } A_{2} \\
\text { (Rs/ha) }\end{array}$ & $\begin{array}{c}\text { Net return } \\
\text { over } \mathrm{A}_{2} \\
\text { (Rs./ha) }\end{array}$ & $\begin{array}{c}\text { Productivity } \\
(\mathrm{qt} / \mathrm{ha})\end{array}$ & $\begin{array}{c}\text { FHP } \\
\text { (Rs/qt) }\end{array}$ & $\begin{array}{c}\text { Cost of } \\
\text { production } \\
\text { (Rs/qt) }\end{array}$ & $\mathrm{BCR}$ \\
\hline & 12490 & 9061 & 3429 & 18.00 & 628 & 504 & 1.38 & 9062 & 9140 & -78 & 15.71 & 460 & 605 & 0.99 \\
\hline 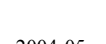 & 10499 & 6875 & 3624 & 13.47 & 763 & 580 & 1.53 & 8056 & 6185 & 1870 & 10.70 & 520 & 579 & 1.30 \\
\hline $2007-08$ & 17106 & 6480 & 10626 & 25.10 & 607 & 274 & 2.64 & 11636 & 9488 & 2148 & 15.83 & 580 & 607 & 1.23 \\
\hline $2010-11$ & 18234 & 7156 & 11078 & 24.73 & 670 & 302 & 2.55 & 12519 & 8770 & 3749 & 15.57 & 615 & 567 & 1.43 \\
\hline CAGR (\%) & 4.53 & -3.5 & 20.12 & 4.41 & -0.04 & -7.58 & 8.32 & 3.8 & 2.09 & 8.04 & 1.62 & 1.74 & -0.8 & 2.08 \\
\hline $\mathrm{CV}(\%)$ & 32.65 & 23.81 & 75.82 & 34.95 & 16.43 & 48 & 39.47 & 22.84 & 16.37 & 82.5 & 20.52 & 15.17 & 15.3 & 20.6 \\
\hline
\end{tabular}

Author's calculation based on data from DES, GOI 


\subsection{Profitability of Competing Crops of Coarse Cereals in India}

The competing crops for the different coarse cereals in different states of India varied. In general, the competing crops for the coarse cereals are mainly pulses and oil seeds. In some part of the country coarse cereals have also faced competition with other crops like cotton and sugarcane. Besides, coarse cereals have also competed with each other.

Maize competes with paddy in Bihar, Punjab and Uttar Pradesh; with soybean in Madhya Pradesh; with groundnut in Rajasthan (Kumar et al., 2004). Sorghum is competing with cotton, green gram and groundnut in Madhya Pradesh (Basavaraja et al., 2005). Sorghum and maize are competing with soybean in Madhya Pradesh (Jaiswal and Hugar, 2011). Cotton, groundnut, pulses and castor are the major crops replacing sorghum in many areas. Soybean is the competing crop, especially in central and western India replacing sorghum. Cotton, sunflower, maize, groundnut, pulses and soybean are replacing pearl millet (CFC and ICRISAT, 2004).

In Bihar, BCR of maize was 3.44 in TE 2010-11 but for paddy it was 1.98. In Uttar Pradesh, it was 1.69 for maize and 2.57 for paddy. In Madhya Pradesh,BCR of maize was 1.64 but that of soybean was 2.59. Moreover, net return from maize cultivation was more than threefold than that of paddy in Bihar but less than one third in Uttar Pradesh.

Sorghum scored BCR of 1.79 in Maharashtra and 2.09 in Andhra Pradesh, 1.67 in Karnataka while maize scored 1.85 in Andhra Pradeshand cotton scored 1.52 and gram 1.28 in Madhya Pradesh.In Rajasthan BCR of sorghumwas2.62 while that of cotton was 5.98 and 3.19 for gram. Net return from sorghum cultivation was observed to be about $12 \%$ of that of cotton in Madhya Pradeshand around $11 \%$ in Rajasthan.

In Gujarat, BCR of pearl millet was 2.47 and 1.98 for groundnut and 2.96 for cotton whereas in Rajasthan BCR of pearl millet was 3.42 and that of green gram was 3.52. Net return from pearl millet cultivation was about one third of cotton in Gujarat and only about $16 \%$ in Rajasthan. BCR of finger millet was 2.55 and 2.24 for cotton in Tamil Nadu. In Karnataka it was 1.43 but 2.53 for sugarcane (Appendix - 1).

\section{CONCLUSIONS}

The study revealed that net return from cultivation of maize was highest in Bihar and lowest in Madhya Pradesh. BCR was also highest in Bihar followed by Karnataka but lowest in Uttar Pradesh. Even though yield was highest in Andhra Pradesh,highest cost of cultivation from input intensive nature of production, BCR was observed to be low.

In Madhya Pradesh BCR was low due to high cost of production and low yield. In Bihar, high yield coupled with low cost of human labour resulted in highest BCR of maize. The cost of cultivation of sorghum was highest in Andhra Pradeshand lowest in Rajasthan. Among the variable inputs, human labour cost was highest in Maharashtra and lowest in Rajasthan. Net return and BCR were highest inAndhra Pradeshand Rajasthan respectively. Lowest BCR observed inMadhya Pradesh was due to low productivity and higher BCR in Rajasthan was due to low cost of cultivation. Cost of cultivation of pearl millet was observed to be highest in Maharashtra and lowest in Rajasthan. Net return was highest in Gujarat and BCR was highest in Rajasthan. Both Net return and BCR were lowest in Karnataka due to low productivity and price of produce.BCR of finger millet cultivation was highest in Tamil Nadu due to higher yield and price of produce but was low in Maharashtra due to higher cost of production mainly human labour. Net return from finger millet cultivation was highest in Tamil Nadu.

Profitability analysis has revealed that, It was observed that there are regional disparities with respect to specific crops of coarse cereals in the country. Net return from $\mathrm{A}_{2}$ for maize was highest in Bihar (Rs. 21,263/ha), for sorghum in Andhra Pradesh (Rs. 8,612/ha), for pearl millet in Gujarat (Rs. 10,777/ha) and for finger millet it was highest in Tamil Nadu (Rs. 11,078/ha) while BCR of maize from $\mathrm{A}_{2}$ was highest in Bihar (3.44), for sorghum and pearl millet in Rajasthan (2.62 and 3.42 respectively) and for finger millet in Tamil Nadu (2.55). In Bihar over the years the net return from maize has increased due to increase in gross return. The increase in gross return was mainly due to 
increase in productivity. Moreover, the increase in yield has resulted in decline in the cost of production but in Uttar Pradesh net return has shown only a marginal increase due to higher increase in cost of cultivation than gross return and lower increase in yield. BCR in Bihar has increased while it has decreased in Uttar Pradesh. Gross return and cost of cultivation from sorghum has increased in both Maharashtra andAndhra Pradesh. The increase in yield was lower inAndhra Pradeshresulted in increase in cost of production but marginal decline of cost of cultivation in Maharashtra. The net return has increased for Andhra Pradesh than Maharashtra due to higher increase in real price of sorghum in Andhra Pradesh. Gross return from cultivation of pearl millet has increased in Gujarat and Rajasthan. In Rajasthan the increase in gross return was coupled with increase in cost of cultivation. Hence, BCR of pearl millet cultivation has declined in Rajasthan while net return from cultivation of pearl millet has increased with increase in cost of production in Gujarat. Gross return from finger millet has increased in both Tamil Nadu and Karnataka. However, cost of cultivation has declined in Tamil Nadu while it has increased in Karnataka. Yield of sorghum has increased in Tamil Nadu but marginal increase in Karnataka. With real price has increased for the latter and marginally declined for the former, the net return from finger millet cultivation has shown growth in Tamil Nadu and Karnataka. The cost of production has declined and BCR increased in Tamil Nadu.

The economic profitability analysis between major coarse cereals and competing crops in the major producing states revealed that in Bihar BCR of maize was higher than paddy and in Madhya PradeshBCR of maize was lower than soybean. In Uttar Pradesh BCR of maize was lower than paddy. BCR of sorghum was lower than maize in Karnataka and in Madhya Pradesh. In Rajasthan, BCR of sorghum was lower than that of pearl millet, cotton and gram. In Gujarat, BCR of pearl millet was lower than cotton whereas in Rajasthan BCR of pearl millet was higher than groundnut. BCR of finger millet was higher than sorghum and groundnut in Tamil Nadu.

The study revealed that the gain or loss of area for the studied coarse cereals related to relative profitability of these crops against their competitors. Since net return from maize cultivation was higher in Bihar than paddy and gram, in Karnataka against sorghum and finger millet and in Andhra Pradesh against sorghum, area under maize has increased for these states but in Uttar Pradeshmaize has lost area due to lower net return against paddy. The loss of area for sorghum was the highest among the major coarse cereals in Andhra Pradesh and Madhya Pradesh due to higher net return from cultivation of its competing crops, maize in Andhra Pradesh and soybean in Madhya Pradesh. Area and net return of pearl millet has declined in Gujarat but it has increased in Rajasthan and its net return was observed to be higher than groundnut in Rajasthan. Moreover, area of finger millet has declined both in Tamil Nadu and Karnataka even though net return from its cultivation has increased due to even higher increase in net return of maize so that finger millet area has declined.

\begin{tabular}{|c|c|c|c|c|c|c|c|c|c|c|}
\hline Crop & Particular & AP & Bihar & Gujarat & Karnataka & MP & Maharashtra & Rajasthan & TN & UP \\
\hline \multirow{6}{*}{ Maize } & Gross return (Rs./ha) & 27840 & 29959 & & 18892 & 7261 & & 15641 & 29841 & 11040 \\
\hline & Cost $A_{2}(\mathrm{Rs} / \mathrm{ha})$ & 15021 & 8696 & & 8121 & 4434 & & 7333 & 13632 & 6530 \\
\hline & Net return over $\mathrm{A}_{2}$ (Rs/ha) & 12819 & 21263 & & 10771 & 2827 & & 8308 & 16209 & 4510 \\
\hline & Profitability (Net return as $\%$ of $A_{2}$ ) & 85.34 & 244.53 & & 132.64 & 63.74 & & 113.3 & 118.90 & 69.07 \\
\hline & Productivity (qt/ha) & 46.00 & 38.00 & & 31.31 & 11.10 & & 19.50 & 46.56 & 16.72 \\
\hline & BCR & 1.85 & 3.44 & & 2.33 & 1.64 & & 2.13 & 2.19 & 1.69 \\
\hline \multirow{6}{*}{ Sorghum } & Gross return (Rs./ha) & 16521 & & & 6993 & 6954 & 13684 & 6133 & 7737 & \\
\hline & Cost $A_{2}(\mathrm{Rs} / \mathrm{ha})$ & 7910 & & & 4185 & 4325 & 7660 & 2340 & 4532 & \\
\hline & Net return over $A_{2}(\mathrm{Rs} / \mathrm{ha})$ & 8612 & & & 2808 & 2629 & 6024 & 3792 & 3205 & \\
\hline & Profitability (Net return as $\%$ of $A_{2}$ ) & 108.88 & & & 67.11 & 60.78 & 78.64 & 162.06 & 70.71 & \\
\hline & Productivity (qt/ha) & 16.08 & & & 7.82 & 11.19 & 13.10 & 4.53 & 7.76 & \\
\hline & BCR & 2.09 & & & 1.67 & 1.61 & 1.79 & 2.62 & 1.71 & \\
\hline \multirow{6}{*}{ Pearl millet } & Gross return (Rs./ha) & & & 18115 & 4497 & & 14045 & 8068 & & 11096 \\
\hline & Cost $A_{2}(\mathrm{Rs} / \mathrm{ha})$ & & & 7338 & 3573 & & 8858 & 2361 & & 4740 \\
\hline & Net return over $A_{2}(\mathrm{Rs} / \mathrm{ha})$ & & & 10777 & 924 & & 5188 & 5707 & & 6356 \\
\hline & Profitability (Net return as $\%$ of $A_{2}$ ) & & & 146.86 & 25.85 & & 58.57 & 241.7 & & 134.1 \\
\hline & Productivity (qt/ha) & & & 21.07 & 8.30 & & 19.01 & 9.31 & & 19.89 \\
\hline & $\mathrm{BCR}$ & & & 2.47 & 1.26 & & 1.59 & 3.42 & & 2.34 \\
\hline \multirow{6}{*}{ Finger millet } & Gross return (Rs./ha) & & & & 12519 & & 13963 & & 18234 & \\
\hline & Cost $A_{2}(\mathrm{Rs} / \mathrm{ha})$ & & & & 8770 & & 13177 & & 7156 & \\
\hline & Net return over $\mathrm{A}_{2}(\mathrm{Rs} / \mathrm{ha})$ & & & & 3749 & & 787 & & 11078 & \\
\hline & Profitability (Net return as $\%$ of $A_{2}$ ) & & & & 42.74 & & 5.97 & & 154.8 & \\
\hline & Productivity (qt $/ \mathrm{ha})$ & & & & 15.57 & & 17.76 & & 24.73 & \\
\hline & $\mathrm{BCR}$ & & & & 1.43 & & 1.06 & & 2.55 & \\
\hline \multirow{2}{*}{ Paddy } & Gross return (Rs./ha) & 37914 & 13636 & 31911 & 34456 & 19386 & 21454 & & 33428 & 24346 \\
\hline & Cost $A_{2}(\mathrm{Rs} / \mathrm{ha})$ & 18264 & 7103 & 12660 & 14945 & 6952 & 17956 & & 18372 & 9477 \\
\hline
\end{tabular}




\begin{tabular}{|c|c|c|c|c|c|c|c|c|c|c|}
\hline Crop & $\begin{array}{r}\text { Particular } \\
\end{array}$ & AP & Bihar & Gujarat & Karnataka & MP & Maharashtra & Rajasthan & TN & UP \\
\hline & Net return over $\mathrm{A}_{2}(\mathrm{Rs} / \mathrm{ha})$ & 19650 & 6533 & 19251 & 19510 & 12434 & 3499 & & 15055 & 14870 \\
\hline & Profitability (Net return as $\%$ of $A_{2}$ ) & 107.59 & 91.98 & 152.06 & 130.54 & 178.86 & 19.48 & & 81.95 & 156.91 \\
\hline & Productivity (qt/ha) & 54.43 & 21.64 & 39.28 & 47.26 & 23.80 & 25.65 & & 47.09 & 37.23 \\
\hline & $\mathrm{BCR}$ & 2.08 & 1.92 & 2.52 & 2.31 & 2.79 & 1.19 & & 1.82 & 2.57 \\
\hline \multirow{6}{*}{ Cotton } & Gross return (Rs./ha) & 33882 & & 46061 & 23836 & 29221 & 29131 & 41588 & 38502 & \\
\hline & Cost $A_{2}(\mathrm{Rs} / \mathrm{ha})$ & 14951 & & 15539 & 9679 & 7940 & 15759 & 6959 & 17173 & \\
\hline & Net return over $\mathrm{A}_{2}(\mathrm{Rs} / \mathrm{ha})$ & 18932 & & 30521 & 14158 & 21281 & 13372 & 34629 & 21330 & \\
\hline & Profitability (Net return as $\%$ of $\mathrm{A}_{2}$ ) & 126.63 & & 196.41 & 146.27 & 268.04 & 84.85 & 497.61 & 124.21 & \\
\hline & Productivity (qt/ha) & 16.87 & & 19.93 & 10.39 & 14.47 & 13.43 & 17.73 & 19.64 & \\
\hline & $\mathrm{BCR}$ & 2.27 & & 2.96 & 2.46 & 3.68 & 1.85 & 5.98 & 2.24 & \\
\hline \multirow{6}{*}{ Ground nut } & Gross return (Rs./ha) & 24716 & & 26080 & 11890 & & 26888 & & 22205 & \\
\hline & Cost $A_{2}(\mathrm{Rs} / \mathrm{ha})$ & 14542 & & 13192 & 7946 & & 14298 & & 12376 & \\
\hline & Net return over $\mathrm{A}_{2}(\mathrm{Rs} / \mathrm{ha})$ & 10174 & & 12888 & 3945 & & 12591 & & 9830 & \\
\hline & Profitability (Net return as $\%$ of $A_{2}$ ) & 69.96 & & 97.70 & 49.64 & & 88.06 & & 79.43 & \\
\hline & Productivity (qt/ha) & 14.92 & & 12.57 & 5.64 & & 15.01 & & 12.35 & \\
\hline & $\mathrm{BCR}$ & 1.70 & & 1.98 & 1.50 & & 1.88 & & 1.79 & \\
\hline \multirow{6}{*}{ Gram } & Gross return (Rs./ha) & 21254 & 21384 & & 11975 & 15100 & 13815 & 12360 & & 17564 \\
\hline & Cost $A_{2}(\mathrm{Rs} / \mathrm{ha})$ & 10400 & 5988 & & 6365 & 5842 & 7568 & 3872 & & 6452 \\
\hline & Net return over $\mathrm{A}_{2}(\mathrm{Rs} / \mathrm{ha})$ & 10854 & 15396 & & 5610 & 9258 & 6247 & 8487 & & 11112 \\
\hline & Profitability (Net return as $\%$ of $A_{2}$ ) & 104.37 & 257.13 & & 88.14 & 158.48 & 82.55 & 219.18 & & 172.22 \\
\hline & Productivity ( $\mathrm{q} / \mathrm{ha})$ & 14.2 & 14.06 & & 8.41 & 10.63 & 8.84 & 7.52 & & 10.83 \\
\hline & $\mathrm{BCR}$ & 2.04 & 3.57 & & 1.88 & 2.58 & 1.83 & 3.19 & & 2.72 \\
\hline \multirow{6}{*}{ Moong } & Gross return (Rs./ha) & 7267 & & & 4142 & & 10166 & 6792 & & \\
\hline & $\operatorname{Cost} A_{2}(\mathrm{Rs} / \mathrm{ha})$ & 2304 & & & 2720 & & 5762 & 1927 & & \\
\hline & Net return over $\mathrm{A}_{2}(\mathrm{Rs} / \mathrm{ha})$ & 4964 & & & 1422 & & 4404 & 4865 & & \\
\hline & Profitability (Net return as $\%$ of $A_{2}$ ) & 215.48 & & & 52.31 & & 76.43 & 252.50 & & \\
\hline & Productivity (qt/ha) & 4.40 & & & 2.23 & & 6.42 & 3.54 & & \\
\hline & BCR & 3.15 & & & 1.52 & & 1.76 & 3.52 & & \\
\hline \multirow{6}{*}{ Soybean } & Gross return (Rs./ha) & & & & & 20249 & 18508 & 14279 & & \\
\hline & Cost $A_{2}(R s / h a)$ & & & & & 7809 & 12616 & 6978 & & \\
\hline & Net return over $\mathrm{A}_{2}(\mathrm{Rs} / \mathrm{ha})$ & & & & & 12439 & 5892 & 7301 & & \\
\hline & Profitability (Net return as $\%$ of $A_{2}$ ) & & & & & 159.29 & 46.70 & 104.64 & & \\
\hline & Productivity (qt/ha) & & & & & 13.87 & 12.45 & 8.34 & & \\
\hline & $\mathrm{BCR}$ & & & & & 2.59 & 1.47 & 2.05 & & \\
\hline \multirow{6}{*}{ Sugar cane } & Gross return (Rs./ha) & & & & 42606 & & 39145 & & & \\
\hline & Cost $A_{2}(\mathrm{Rs} / \mathrm{ha})$ & & & & 16859 & & 21097 & & & \\
\hline & Net return over $\mathrm{A}_{2}(\mathrm{Rs} / \mathrm{ha})$ & & & & 25747 & & 18047 & & & \\
\hline & Profitability (Net return as $\%$ of $A_{2}$ ) & & & & 152.72 & & 85.54 & & & \\
\hline & Productivity (qt/ha) & & & & 334.97 & & 258.87 & & & \\
\hline & $\mathrm{BCR}$ & & & & 2.53 & & 1.86 & & & \\
\hline
\end{tabular}

Author's calculation based on data from DES, GOI

\section{References}

[1] Basavaraja, H., Hugar, A.Y., Mahajanshetti, S.B., Angadi, V.V. and Rao, B. D. (2005). Kharif Sorghum in Karnataka: An Economic Analysis. Agricultural Economics Research Review, 18:223-240

[2] CFC and ICRISAT (2004). Alternative Uses of Sorghum and Pearl Millet in Asia: proceedings of the Expert Meeting, 1-4 July 2003, ICRISAT, Andhra Pradesh, India

[3] Jaiswal, A. and Hugar, L. B. (2011). An economic analysis of soybean cultivation vis-à-vis its competing crops in Madhya Pradesh, Karnataka Journal of Agricultural Sciences, 24 (4): 591 592

[4] Kumar, R., Singh, N.P., Singh, R.P and Vasisht, A.K. (2004). Adoption Pattern of Maize Techology in Northern India: Impact on Farm Earning and Trade., Agricultural Economics Research Review, 17:29-42 